\title{
Investigation of acute effects of Hypericum perforatum (St. John's Wort-Kantaron) treatment in experimental thermal burns and comparison with silver sulfadiazine treatment
}

\author{
Selahattin Kıyan, M.D.,' Yiğit Uyanıkgil, M.D., ${ }^{2}$ Yusuf Ali Altuncı, M.D., ${ }^{1}$ \\ Türker Çavuşoğlu, M.D., ${ }^{2}$ Emel Öykü Çetin Uyanıkgil, M.D., ${ }^{3}$ Fatih Karabey, M.D. ${ }^{4}$
}

${ }^{1}$ Department of Emergency Medicine, Ege University Faculty of Medicine, Izmir

${ }^{2}$ Department of Histology and Embryology, Cord Blood, Cell and Tissue Research and Application Centre, Ege University Faculty of Medicine, Izmir ${ }^{3}$ Department of Biopharmaceutics and Pharmacokinetics, Ege University Faculty of Pharmacy, Izmir

${ }^{4}$ Department of Biology, Ege University Faculty of Science, Izmir

\begin{abstract}
BACKGROUND: Hypericum perforatum (HP) (St. John's Wort-Kantaron) has been used widely for the treatment of burn injuries for many years in traditional Turkish medicine. The aim of study was to investigate HP treatment in experimental thermal burns and compare it with silver sulfadiazine (SS) treatment.

METHODS: Thirty-five rats were randomly assigned to one of the five groups, 7 rats in each. A second-degree thermal burn was created on the dorsal sites of rats by exposing an area of $4 \times 4 \mathrm{~cm}$ to $100^{\circ} \mathrm{C}$ boiled water for 10 seconds. All groups were provided with irrigation for three (3) minutes with $50 \mathrm{cc}$ saline solution (SS). Group I (Control Group) was not administered any treatment. Group 2 (Burn Control Group) was administered only irrigation, Group 3 (topical silver sulfadiazine [SS]) was administered SS twice a day, Group 4 (the Topical HP Group) was administered HP four times a day (every six hours), Group 5 (treatment with agent -gel-) was administeredother topical material used for the preparation of HP four times a day (every six hours). Wound site healing on the skin was histopathologically evaluated.
\end{abstract}

RESULTS: It was found that collagen discoloration of the HP treatment group was localized in the lower part of the epidermal layer and did not go up to the depth of dermis compared to the other groups, and epidermis, hair follicles and sebaceous glands remained protected compared to the groups administered burn, gel and SS in every hour of the experiment and it was the group closest to the control group structurally. It was determined that the epidermal thickness and the number of vessels of the HP Group were significantly higher compared to the other groups $(p<0.05)$, which was the group closest to the control group in terms of these parameters and these numbers did not show any difference within hours $(p>0.05)$. The number of degenerated hair follicles in the HP Group was significantly less than the other groups $(p<0.05)$, and it was determined that the total number of hair follicles significantly increased in the twenty-fourth $(p<0.05)$ and this number did not differ by the control group $(p>0.05)$.

CONCLUSION: Administration of HP four times a day within the first 24 hours is clearly effective in wound healing in the experimental thermal second degree burn modality and is significantly superior to SS treatment.

Keywords: Hypericum perforatum; silver sulfadiazine; thermal burns; wound healing.

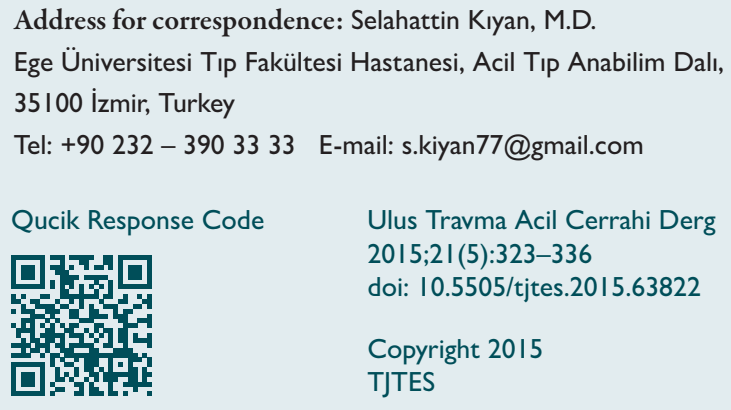

\section{INTRODUCTION}

Hypericum perforatum (HP) L., locally known as "Kantaron" in Turkey, and St. John's Wort in English, is a perennial herb from the Hypericaceae family grown in Europe, Asia, North Africa and the United States. ${ }^{[1]}$ HP has been used for medicinal purposes for centuries. It is used for the treatment of mild to moderate depression, ${ }^{[2]}$ healing wounds (acute and contused injuries), ${ }^{[3]}$ first-degree burns, ${ }^{[3]}$ relieving myalgia (muscle pain, ${ }^{[3]}$ seasonal affective disorder, ${ }^{[4]}$ obsessive-compulsive disorder, ${ }^{[5]}$ pre-menstrual syndrome, ${ }^{[6]}$ menopause, ${ }^{[7]}$ 
paediatric nocturnal incontinence, ${ }^{[8]}$ and also as pain reliever, tranquillizer, parasite lowering, ulcer healing agent. ${ }^{\left[{ }^{9]}\right.}$ It is used for many disorders in Turkish folk medicine. Moreover, it has been recorded that the olive oil macerate of the flowering herbs is a popular externally applied home-remedy for the rapid recovery of cuts and burns. ${ }^{[10,11]}$ The dried flowering parts are placed inside a jar of olive oil and kept under sunshine for abour four weeks. For the preparation of an efficient home-remedy, the key procedure is described as "the content of the jar should be exposed to the heat of the sun and the breeze of the night". ${ }^{[2]}$

Burn patients are usually young people, and burns affect a very large population. They are usually simple burns and the rate of mortality is low. Injuries usually occur at home and a large proportion of patients admitted to the emergency rooms due to burn injuries are treated in and discharged from the emergency rooms. ${ }^{[13]}$ However, no effective, local burn treatment exists even today. There is a need for a new molecule that will reduce pain in patients with burns, eliminate negative cosmetic results and accelerate burn healing.

The literature review conducted draws attention to the fact that the number of clinical and experimental studies on the effect of HP in patients with burns and in experimental burn modalities is very few and insufficient, and also these studies are in contact-type burn modality. The first study in which thermal (scalding) type burn modality has been used is our study. Our aim in this study was to determine whether or not HP, thought to be effective in burn and wound healing in folkloric medicine for a long time, is effective in wound healing for experimental thermal (scalding) type burns and to compare it with other burn treatments.

\section{MATERIALS AND METHODS}

\section{Experimental Procedure}

This study was conducted considering the Guide for the Care and Use of Laboratory Animals-Institute of Laboratory Animal Resources Commission on Life Sciences National Research Council (USA) criteria. Throughout the experiment, animals were handled according to the suggested international ethical guidelines for the care of laboratory animals under the audit of Ege University Commission of Animal Ethics. During the experiment, they were kept in $24+1{ }^{\circ} \mathrm{C}$ at room temperature in appropriate lighting conditions, and in 12 hour-light-dark cycle in cages cleaned once every day. Bait and water were given as ad libitum, shavings were used as mounting. Twelve hours before the study, they were given water. Controls and upkeep was done non-stop and regularly.

\section{Experimental Protocol}

Adult female rats of Wistar-albino species, weighing 195 to $245 \mathrm{~g}$ in average that were given $200 \mathrm{mg} / \mathrm{kg}$ paracetamol (Perfalgan ${ }^{\circledR}$, Bristol-Myers Squibb) through intra-peritoneal $28 \mathrm{G}$ insulin injection 25 minutes before the process for their analgesia were then anaesthetized by administering a combination of $10 \mathrm{mg} / \mathrm{kg}$ xylazine and $50 \mathrm{mg} / \mathrm{kg}$ ketamine intraperitoneally and then the experimental stage was started. An area of $4 \times 4 \mathrm{~cm}$ on dorsal sites of rats was shaved using a razor blade machine. A $4 \times 4 \mathrm{~cm}$ area on both opposing surfaces of a plastic cuboidal shape bottle was cut and fixed to the shaven area on the dorsal sites of rats with the help of a polyethylene membrane and $100^{\circ} \mathrm{C}$ water was poured into the bottle from above. A thermal (scalding) type burn was created on the shaven area by exposure to water for 10 seconds. One minute later, all the groups were provided with irrigation for three minutes with $50 \mathrm{cc}$ saline solution. ${ }^{[14,15]}$

\section{Grouping of Subjects}

Group I (Control Group) was not administered any treatment or therapy. Group 2 (Burn Control Group) did not receive any treatment after the occurrence of the thermal burn and irrigation with saline solution. Group 3 (Topical Silver Sulfadiazine [SS]) received SS twice a day topically after irrigation with saline solution. Group 4 (Topical HP Group) received the prepared topical HP four times a day (every six hours). Group 5 (Group Treated with Agent -Gel-) received other topical material used for the preparation HP, four times a day.

The wound site was closed with sterile dry gauze dressing which did not contain any topical agent after topical treatment and irrigation with saline solution, and the rats were dressed a specially prepared burn clothing and secured specially not to put pressure on the wound. In addition, $500 \mathrm{mg}$ paracetamol was added to every $500 \mathrm{ml}$ of drinking water of the rats for the purpose of analgesia.

Table I. Histopathological scoring table - Modified Verhofstad Scoring ${ }^{[16]}$

\begin{tabular}{ccccccc}
\hline Score & Oedema & PMNL infiltration & Collagen discolourization & Vascular injury & Hair follicle damage & GI. sebasea damage \\
\hline 0 & None & Normal & None & None & None & None \\
1 & Mild & Mild & Mild & Mild & Mild & Mild \\
2 & Significant & Significant & Significant & Significant & Significant & Significant \\
3 & Intense & Massive & Intense & Intense & Intense & Intense \\
\hline
\end{tabular}

The samples were examined based on the following seven parameters: neutrophil [polymorphonuclear granulocytes (PMNL)], lymphocyte density, vascularity, fibroblast proliferation, the amount of oedema, collagen density and necrosis. 


\section{Microscopic Material-Method and Histopathological Evaluation}

Incisional biopsies of square shaped $|\times| \mathrm{cm}$ in size were taken from the dorsal skins of the rats in hours 4, 8 and 24. For light microscopic sections, sections of $5 \mu$ in Leica RM 2 I 45 model microtome were taken into $45{ }^{\circ} \mathrm{C}$ water bath. $\mathrm{A}$ microwave oven (Arçelik MD554) was used for adhering the sections to the blades thoroughly and paraffin removal. After fixation with $4 \%$ paraformaldehyde, skin tissue was stained with hematoxylin-eosin following standard procedures and examined by histologists under a light microscope. Biopsies taken from the groups were evaluated by the Modified Verhofstad Histopathological scoring ${ }^{[16]}$ system (Table I) by two blinded histologists who were not aware of the groups from which the biopsies were taken. Results obtained from this scoring were compared and scored by taking arithmetic average of the scores given. In addition, wound healing on the skin and epidermis thickness, inflammatory cell infiltration (neutrophils, monocytes, and macrophages), number of degenerated and total hair follicles in the wound site was also included in the evaluation histopathologically.

\section{The Preparation of Placebo Gel}

Placebo gel formulation was prepared by dispersing $7.5 \% \mathrm{w} / \mathrm{w}$ carboxy methyl cellulose (Na-CMC, average $\mathrm{Mw} \sim 90.000$, Sigma, USA) in distilled water and adding $2 \%$ ethanol (TEKEL, Turkey) to form a homogeneous dispersion under continuous stirring until homogeneous gel was formed.

\section{The Preparation of Gel Containing HP Methanol Extract}

Gel formulation was prepared by dispersing $7.5 \% \mathrm{w} / \mathrm{w}$ car- boxy methyl cellulose ( $\mathrm{Na}-\mathrm{CMC}$, average $\mathrm{Mw} \sim 90.000$, Sigma, USA) in distilled water to form a homogeneous dispersion. $5 \%$ HP methanol extract was dissolved in $2 \%$ ethanol (TEKEL, Turkey) and the solution was added gently to $\mathrm{Na}$ CMC dispersion under continuous stirring. The mixture was stirred gently until homogeneous gel was formed.

\section{Statistical Analysis}

Data obtained from the study was entered into SPSS 15.0 software and then analysed. Of continuous variables, median, minimum and maximum values were presented. Compliance of these variables with the normal distribution was investigated. It was concluded that requirements of compliance with the normal distribution were not met for all the variables and thus, non-parametric methods were preferred. Comparisons of independent groups were performed using the Kruskal-Wallis and Mann-Whitney $U$ test methods, while comparisons of dependent groups were performed with the Wilcoxon Signed Ranks test method. The difference between the groups was considered statistically significant in the case of " $p$ " value being less than 0.05 .

\section{RESULTS}

\section{Weight Analysis Results}

All subjects in the Groups $(n=35)$ were divided in a manner that each group would contain 7 subjects. Their weights were measured before the process. Data was collected by measuring weights of all the biopsies taken for post-burn evaluation and after their dry weights were added, by measuring their final weights before the subjects were sacrificed in hour 24 . No statistically significant difference in weight was found between the groups.
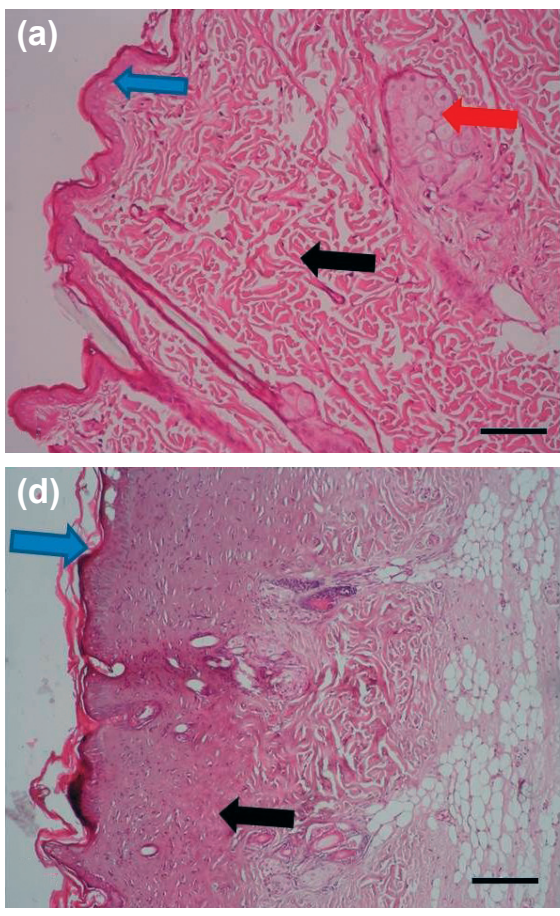
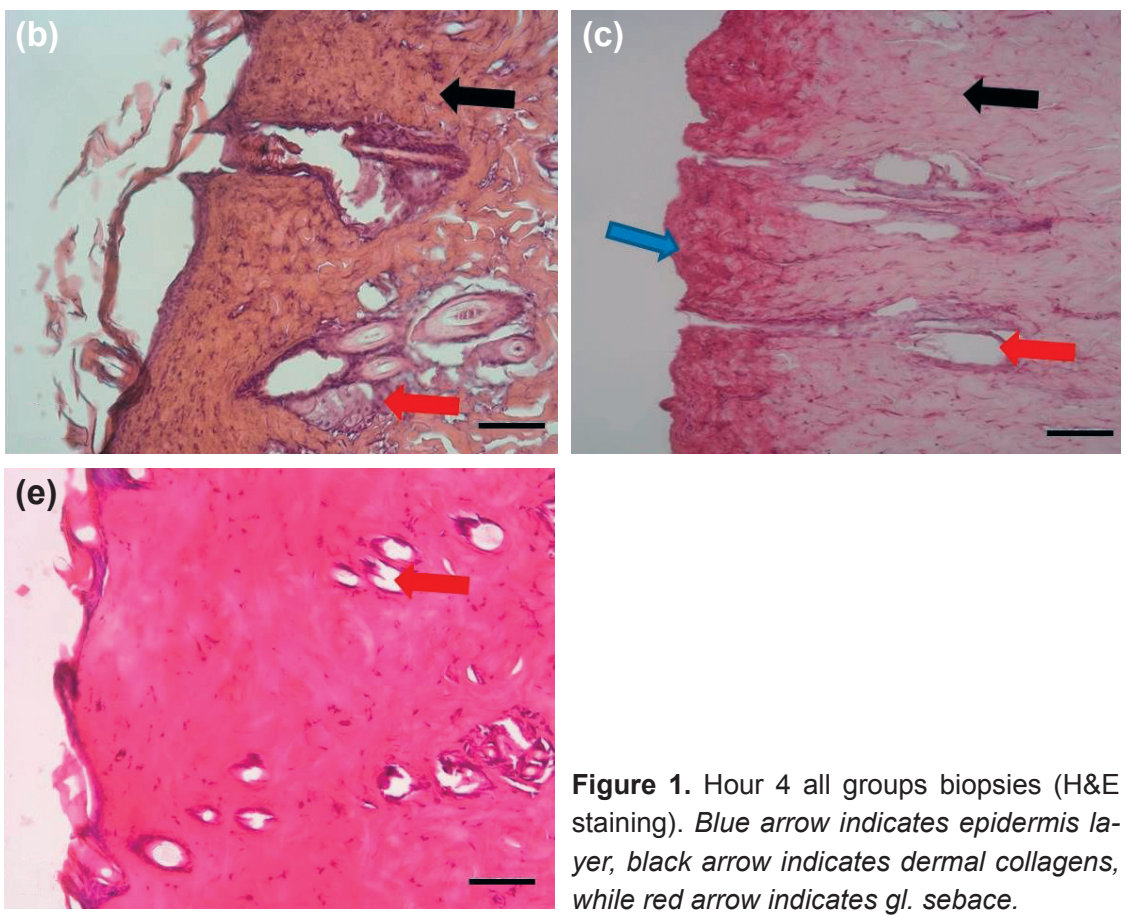

Figure 1. Hour 4 all groups biopsies (H\&E staining). Blue arrow indicates epidermis layer, black arrow indicates dermal collagens, while red arrow indicates gl. sebace. 


\section{Histopathological Analysis Results}

It was histopathologically observed in the examinations of the biopsies in hours 4, 8 and 24 in the figures of biopsies B (Ib, 2b, 3b, 4b, 5b, 6b- Burn Group), biopsies C (Ic, 2c, 3c, 4c, 5c, 6c - SS Group) biopsies E (Ie, 2e, 3e, 4e, 5e, 6e - Gel Group) that the biopsies were affected by thermal burn (Figs. I-6). Histological evaluation of the skin tissue revealed that hair follicles, sebaceous glands were affected in degenerative sense, the layer of epidermis thinned and collagens in the dermis gained a discolourized appearance. It was determined that collagen discolourization particularly in sections $(2 a, 2 b$, 2c, 2d, 2e, 4a, 4b, 4c, 4d, 4e, 6a, 6b, 6c, 6d, 6e) for which Mallory Azan staining (Figs. 2, 4, 6) were made appeared quite noticeably. It was observed in figures of biopsies $D$ (Fig. I-6) (Id, 2d, 3d, 4d, 5d, 6d - HP Group) that collagen discolouration in sections of every hour of the experiment implemented was localized in the lower part of epidermal layer and did not go up to the depth of dermis compared to the other
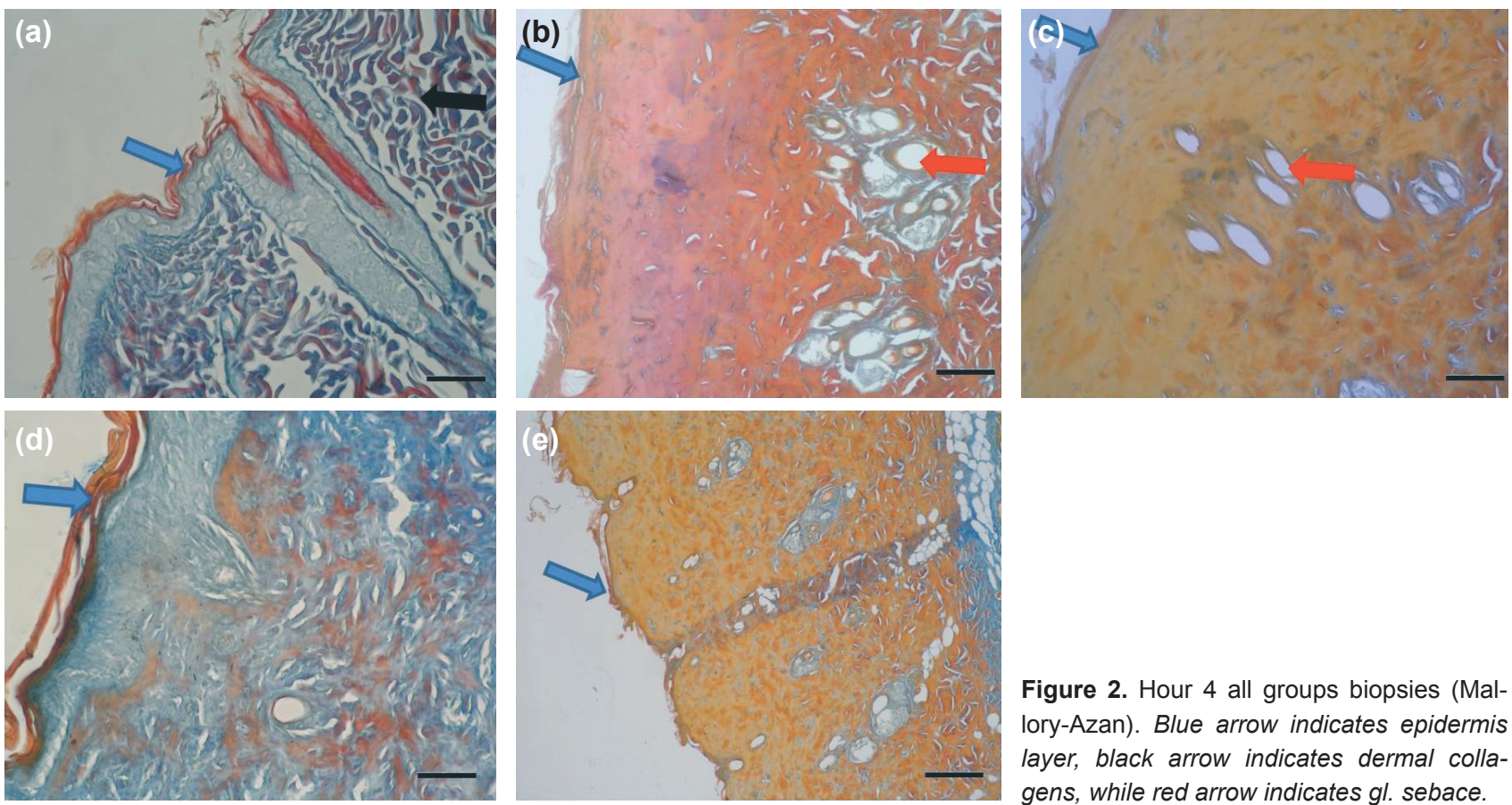

Figure 2. Hour 4 all groups biopsies (Mallory-Azan). Blue arrow indicates epidermis layer, black arrow indicates dermal collagens, while red arrow indicates gl. sebace.
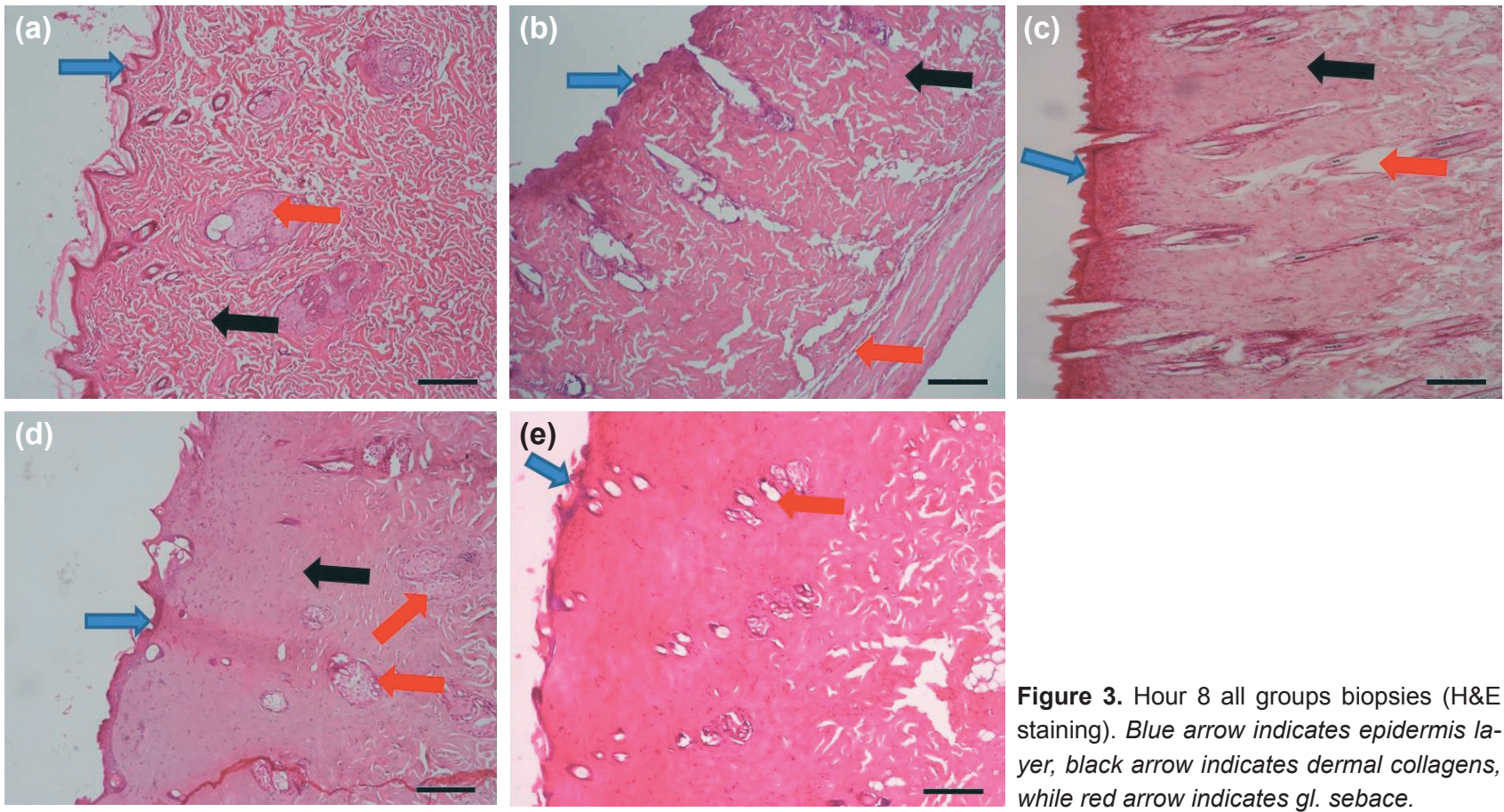

Figure 3. Hour 8 all groups biopsies (H\&E staining). Blue arrow indicates epidermis layer, black arrow indicates dermal collagens, while red arrow indicates gl. sebace. 

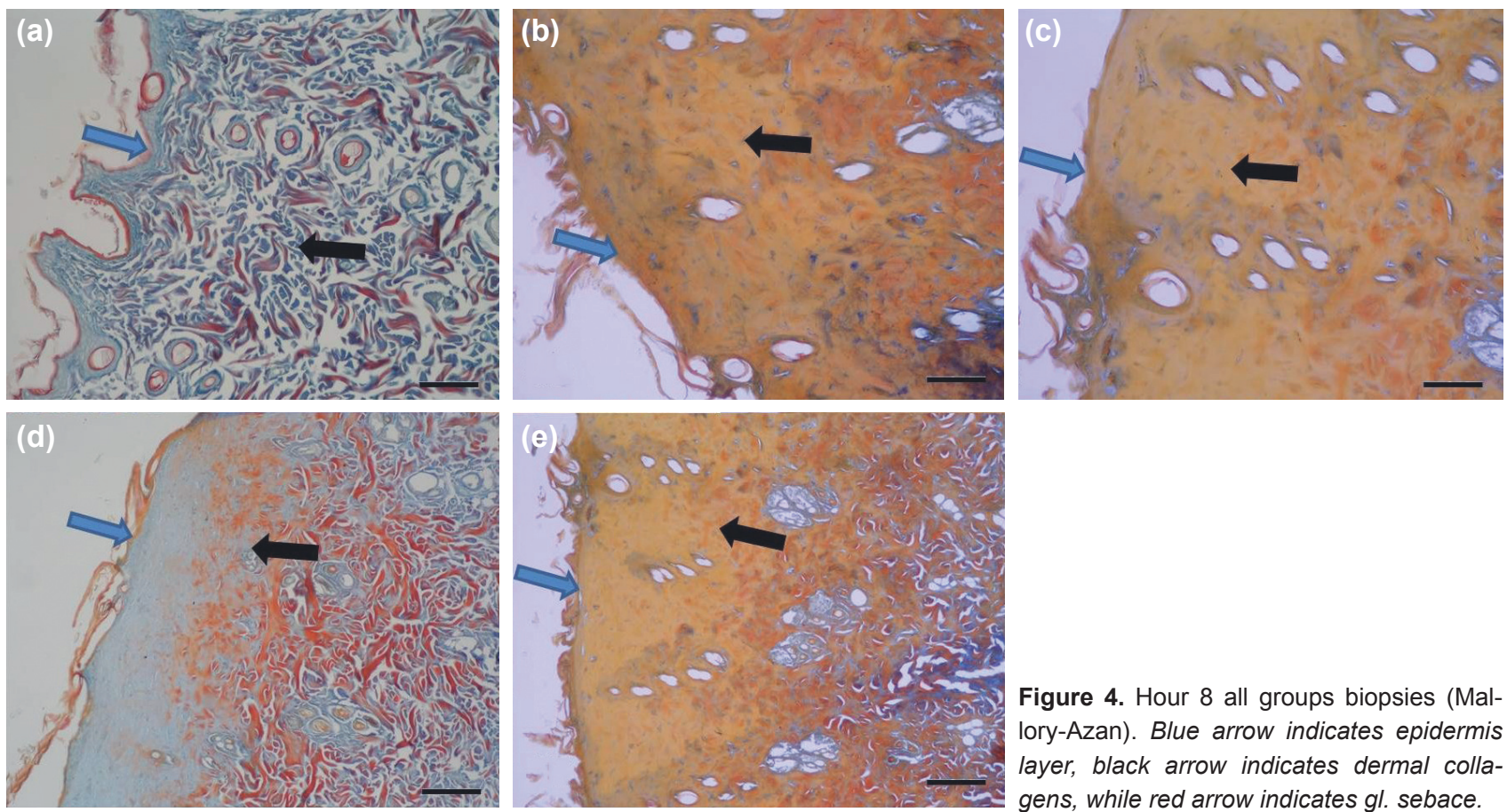

Figure 4. Hour 8 all groups biopsies (Mallory-Azan). Blue arrow indicates epidermis layer, black arrow indicates dermal collagens, while red arrow indicates gl. sebace.
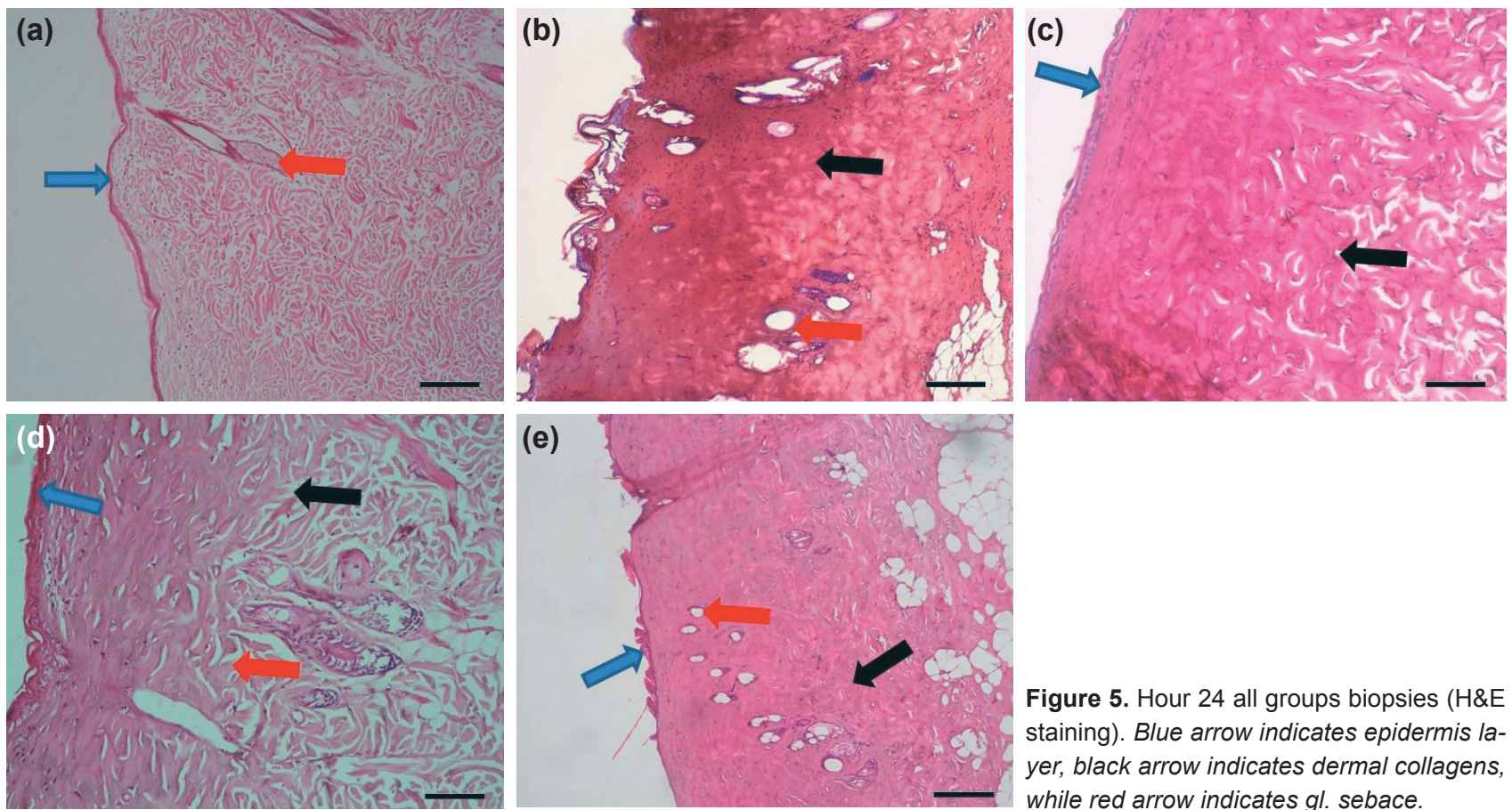

Figure 5. Hour 24 all groups biopsies (H\&E staining). Blue arrow indicates epidermis layer, black arrow indicates dermal collagens, while red arrow indicates gl. sebace.

groups. In addition, it was found that epidermis, hair follicles and sebaceous glands remained protected in the HP treated group compared to the groups administered burn, gel and SS in every hour of the experiment and it was the group closest to the control group structurally.

\section{Results of the Statistical Analysis}

Evaluation of Epidermal Thickness and Number of
Vessels: It was determined during the inter-group comparison by biopsy hours that the epidermal thickness (Table 2) and the number of vessels (Table 3 ) of the HP Group in hours 4,8 and 24 were significantly higher $(p<0.05)$ compared to the gel and SS group, and this number did not show any difference within hours $(p>0.05)$. At the same time, the HP Group was found to be the group closest to the control group in terms of epidermal thickness and number of vessels (Figs. 7, 8). 

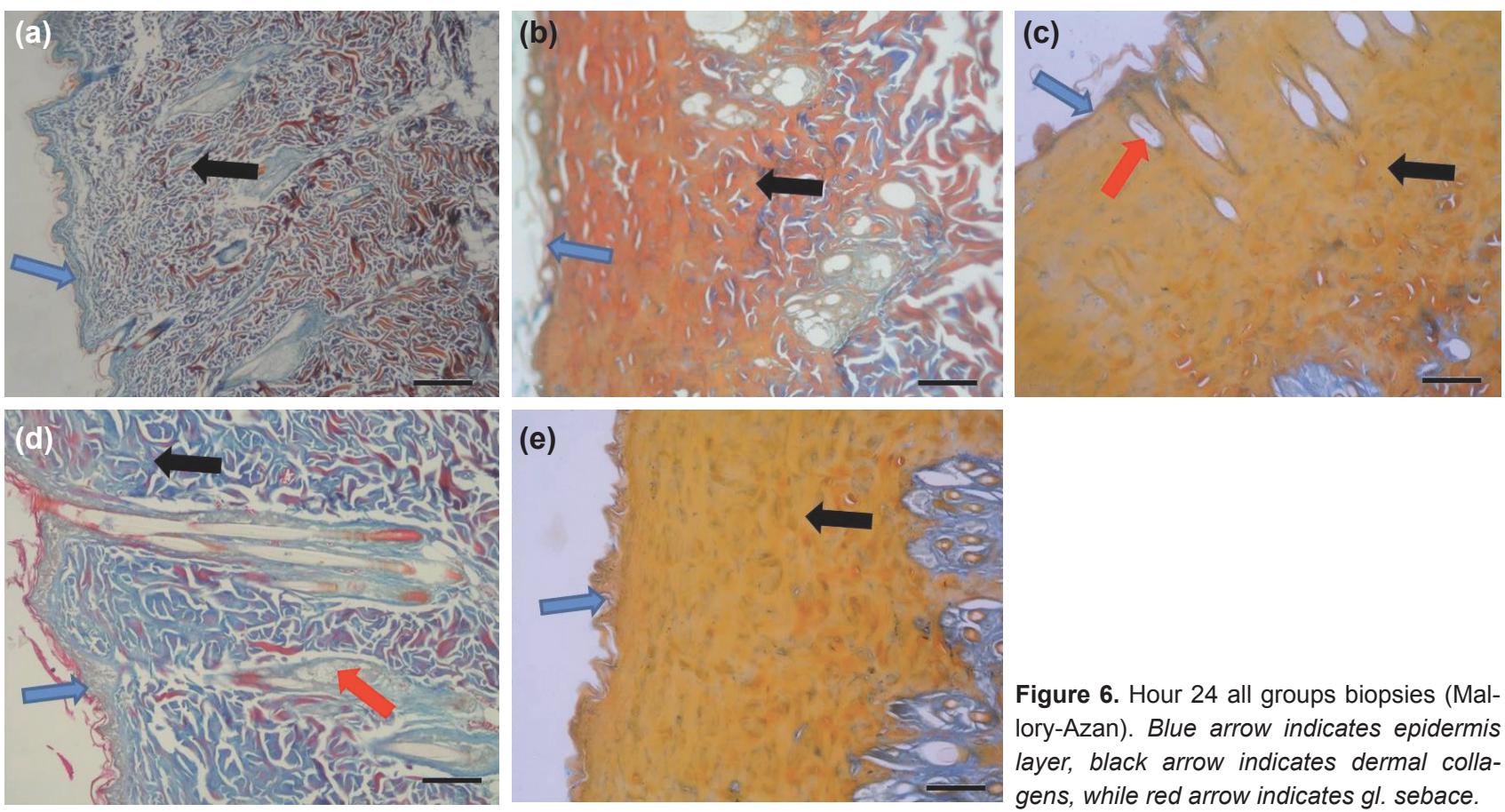

Figure 6. Hour 24 all groups biopsies (Mallory-Azan). Blue arrow indicates epidermis layer, black arrow indicates dermal collagens, while red arrow indicates gl. sebace.

\section{Evaluation of Number of Degenerated Hair} Follicles and Total Number of Hair Follicles

It was determined during the inter-group comparison by biopsy hours that the epidermal thickness and the number of vessels of the HP Group in hours 4, 8 and 24 were significantly higher $(p<0.05)$ (Tablo 4$)$ compared to all the groups, and this number did not show any difference within hours $(p>0.05)$. It was observed that the total number of hair fol- licles in hours 4 and 24 significantly increased only in the HP Group among all the groups. Samples taken in hour 4 from all the groups had a lower rate of total hair follicles than the control group $(p<0.05)$ (Tablo 5). The HP Group had a significantly higher number of hair follicles than the gel, burn and SS Groups $(p<0.05)$ at the end of hour 24 , and this number did not show any difference by the control group $(p>0.05)$ (Figs. 9, 10).

Table 2. Inter-group comparison of epidermal thickness of biopsy samples from hours 4, 8 and 24

\begin{tabular}{lllcccc}
\hline Epidermal thickness $(\boldsymbol{\mu m})$ & Groups & Mean & Standard deviation & Median & Minimum & Maximum \\
\hline Hour 4 & Group I (Control) & 36.43 & 2.36 & 36.47 & 33.07 & 39.33 \\
& Group II (Burn) & 9.01 & 0.90 & 8.83 & 7.99 & 10.52 \\
& Group III (SS) & 11.99 & 1.60 & 12.33 & 9.35 & 13.90 \\
& Group IV (HP) & 27.47 & 2.13 & 27.63 & 24.98 & 31.00 \\
& Group V (Gel) & 11.67 & 1.53 & 12.15 & 9.04 & 13.35 \\
Hour 8 & Group I (Control) & 35.69 & 2.65 & 36.20 & 31.99 & 38.74 \\
& Group II (Burn) & 9.72 & 1.49 & 9.36 & 7.85 & 12.02 \\
& Group III (SS) & 11.68 & 1.27 & 11.83 & 9.90 & 13.12 \\
& Group IV (HP) & 29.49 & 2.56 & 28.74 & 26.34 & 33.32 \\
Hour 24 & Group V (Gel) & 12.61 & 1.58 & 12.75 & 9.98 & 14.97 \\
& Group I (Control) & 35.74 & 2.63 & 35.48 & 31.91 & 39.34 \\
& Group II (Burn) & 10.77 & 1.22 & 10.66 & 9.03 & 12.23 \\
& Group III (SS) & 13.15 & 1.93 & 13.86 & 9.98 & 15.78 \\
& Group IV (HP) & 31.75 & 2.13 & 32.12 & 28.77 & 34.77 \\
& Group V (Gel) & 13.82 & 1.06 & 13.76 & 12.64 & 15.77 \\
\hline
\end{tabular}

SS: Silver sulfadiazine; HP: Hypericum perforatum. 
Table 3. Inter-group comparison of the numbers of vessels of biopsy samples from hours 4,8 and 24

\begin{tabular}{|c|c|c|c|c|c|c|}
\hline Number of vessels & Groups & Mean & Standard deviation & Median & Minimum & Maximum \\
\hline \multirow[t]{5}{*}{ Hour 4} & Group I (Control) & 37.86 & 2.04 & 38 & 35 & 41 \\
\hline & Group II (Burn) & 8.29 & 1.38 & 9 & 6 & 10 \\
\hline & Group III (SS) & 13.43 & 2.57 & 13 & 10 & 18 \\
\hline & Group IV (HP) & 23.57 & 3.55 & 22 & 19 & 29 \\
\hline & Group V (Gel) & 13.29 & 1.70 & 14 & 11 & 16 \\
\hline \multirow[t]{5}{*}{ Hour 8} & Group I (Control) & 35.71 & 4.82 & 37 & 28 & 42 \\
\hline & Group II (Burn) & 7.71 & 2.29 & 8 & 4 & II \\
\hline & Group III (GS) & 16.14 & 2.27 & 16 & 13 & 19 \\
\hline & Group IV (HP) & 23.57 & 2.37 & 24 & 20 & 27 \\
\hline & Group V (Gel) & |3.7| & 1.80 & 14 & II & 16 \\
\hline \multirow[t]{5}{*}{ Hour 24} & Group I (Control) & 34.00 & 6.16 & 37 & 25 & 41 \\
\hline & Group II (Burn) & 6.57 & 2.23 & 6 & 4 & 10 \\
\hline & Group III (SS) & 14.86 & 2.54 & 15 & 12 & 19 \\
\hline & Group IV (HP) & 24.57 & 2.82 & 24 & 21 & 28 \\
\hline & Group V (Gel) & 16.71 & 2.29 & 16 & 14 & 21 \\
\hline
\end{tabular}

SS: Silver sulfadiazine; HP: Hypericum perforatum.

\section{Evaluation by the Modified Verhofstad} Histopathological Scoring ${ }^{[16]}$ System Inter-group and intra-group tests were not performed statis- tically because histopathological scores of each of the groups did not vary within themselves in the evaluation of the groups performed based on the Modified Verhofstad histopathologi-

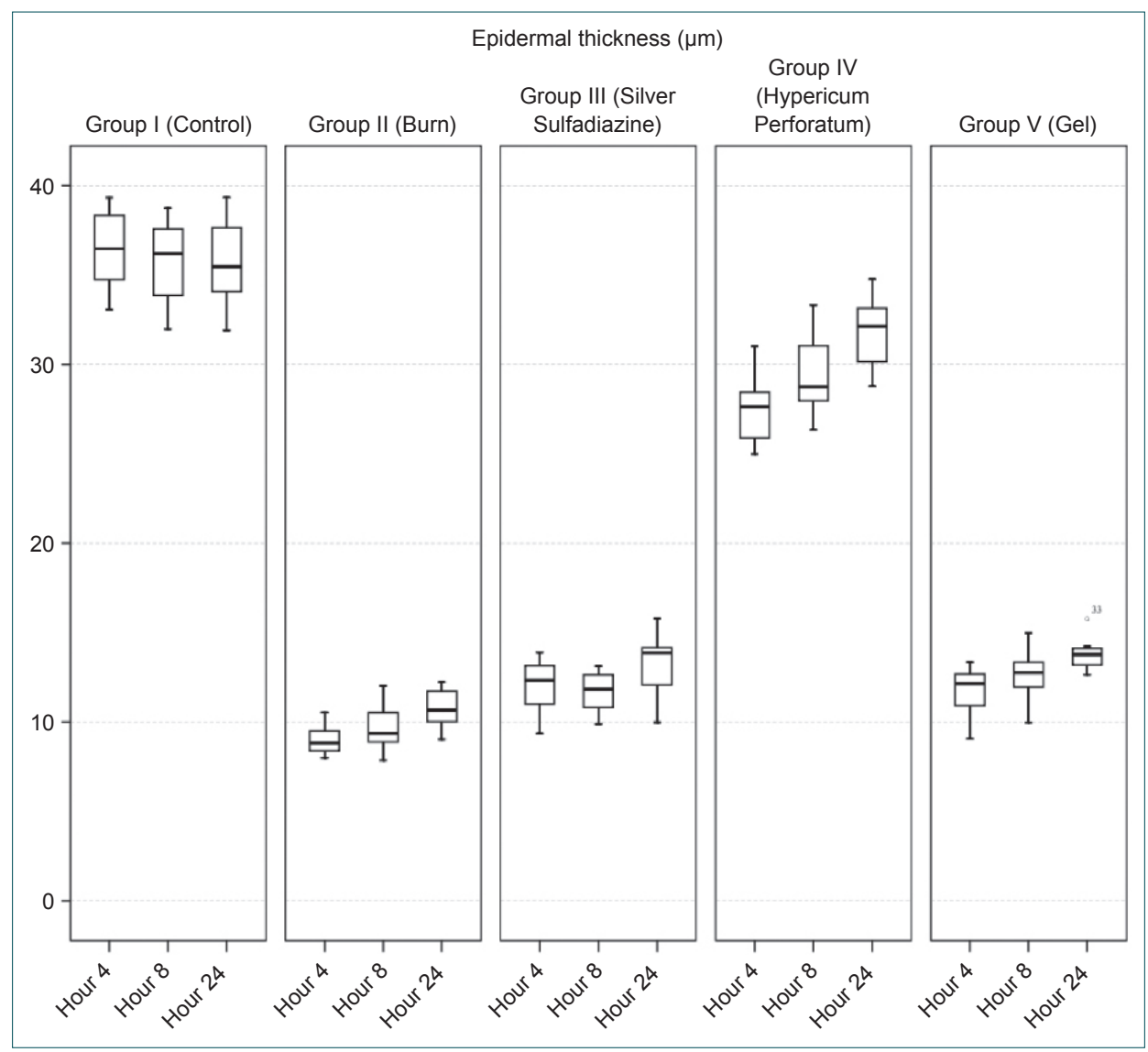

Figure 7. Epidermal thickness by biopsy hours. 


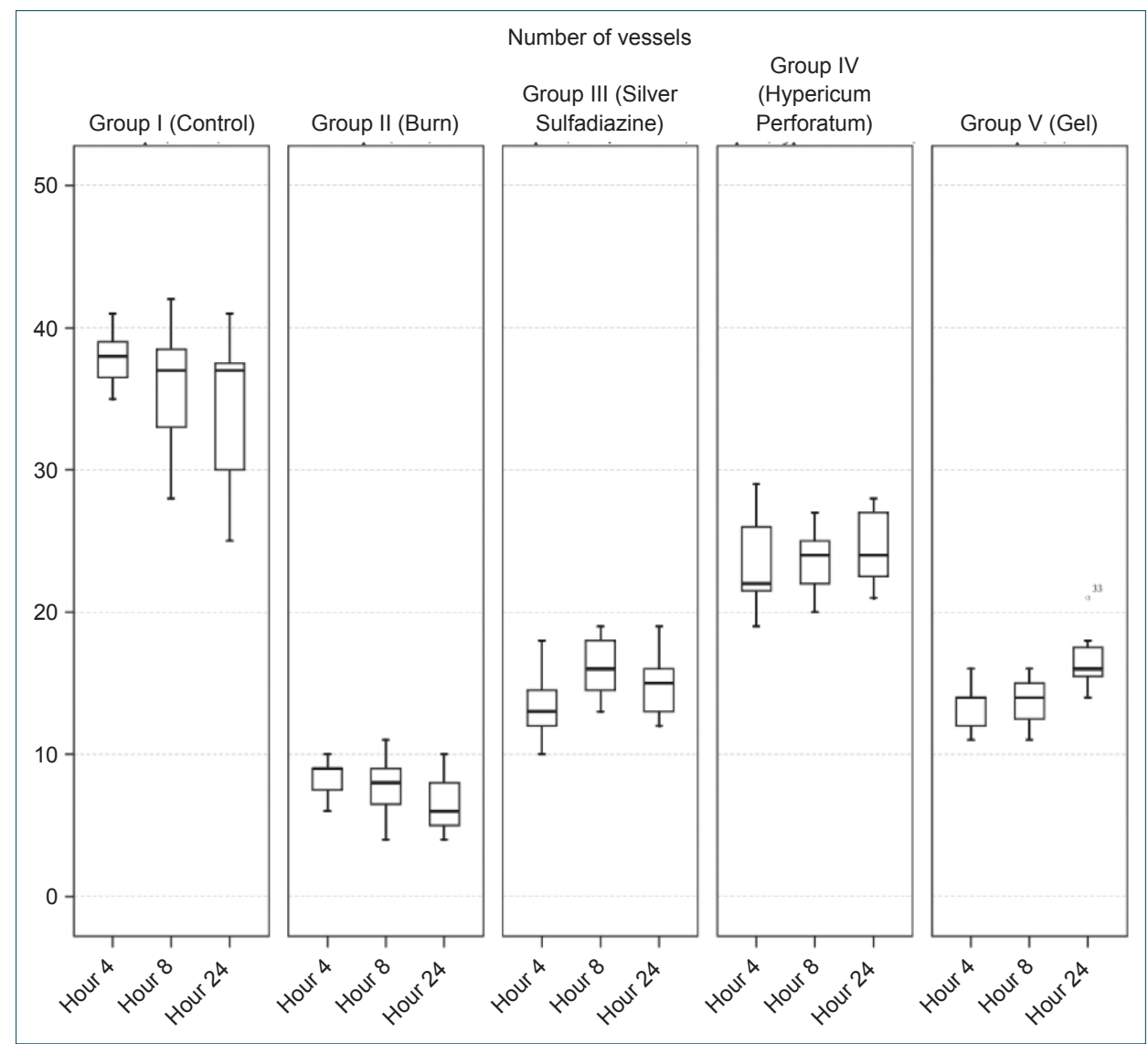

Figure 8. Number of vessels by biopsy hours.

cal scoring system (oedema, vascular damage, PMNL infiltration, collagen discolourization, hair follicles damage, Glandula Sebacea damage). Therefore, interpretation was made based on the average scores of the groups.

When the mean scores for edema, PMNL infiltration, collagen discoloration, vascular damage, hair follicles damage, and Glandula Sebacea damage of all the groups were evaluated, it was observed that the HP Group had the lowest values both in the inter-group and intra-group evaluations (Table 6) (Fig. II).

\section{DISCUSSION}

It was found that HP treatment was significantly superior to other treatment groups in the second degree experimental thermal burn modality. HP, administered four times a day in the first 24 hours, treated burnt skin almost as closely as to the control group. It was realised that the HP Group was the best group in terms of epidermal thickness and number of vessels which are the most important findings in wound healing and that it was the group closest to the control group. It was discovered that HP was significantly effective for wound healing due to the fact that collagen discoloration, another important parameter in terms of wound healing, localized in the lower part of the epidermal layer and did not go up to the depth of dermis. The number of degenerated hair follicles were significantly less, it caused an increase in the number of hair follicles within hours and the epidermis remained protected. HP both reduced destructive effects of acute phase burns and provided healing within hours.

The sequence of events that repairs damage is categorized into three overlapping phases: inflammation, proliferation, and tissue remodeling. The final step of the proliferative phase is epithelialization, which involves migration, proliferation, and differentiation of epithelial cells from the wound edges to resurface the defect. ${ }^{[17]}$ It was observed in our study that the HP-treated group was the group in which the epidermal thickness was the most protected in the early hours and this thickness significantly increased within hours at the same time. The epidermal thickness was almost equal to the epidermal thickness of the control group at the end of hour 24. Epidermal integrity is an important parameter for prevention of wound infection and smooth, sequel-free wound healing cosmetically. HP offers some benefits for the treatment of second degree burns, and it may offer benefits even for more severe (Third Degree) burns with this feature.

Collagen is the main structural protein component of connective tissue. Chvapil et al. ${ }^{[18]}$ have demonstrated that collagen sponge enhances the connective tissue formation and increas- 


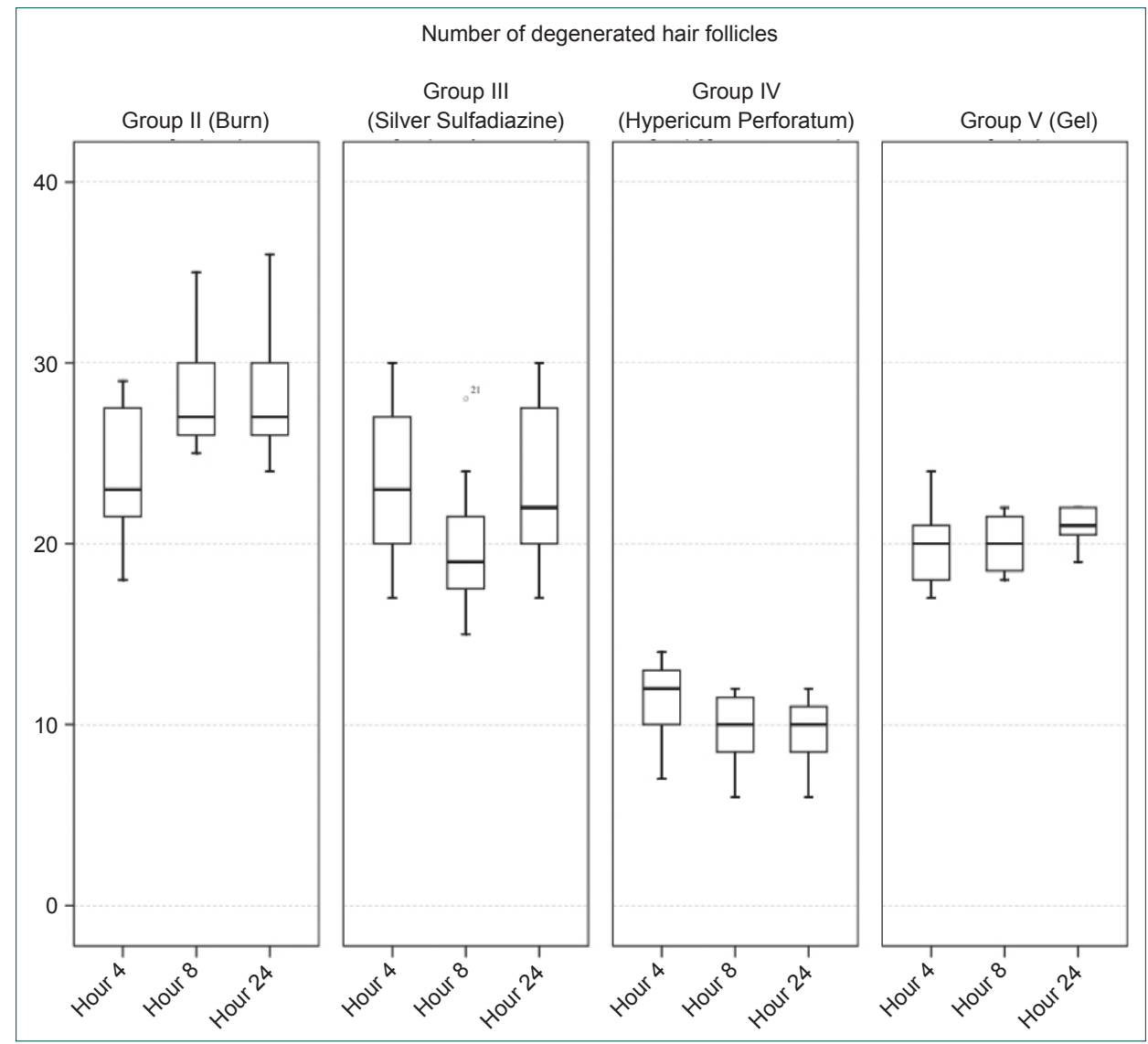

Figure 9. Number of degenerated hair follicles by biopsy hours.

es the vascularization of the repaired tissue. Therefore, it is known that collagen effectively increases the process of healing. Motta et al. ${ }^{[19]}$ have revealed that collagen also enhances suitably modulated collagen lysis and favours a more orderly fibroblast proliferation, probably by acting as a recruiting factor for these cells and taking part in their metabolism directly. It was observed in this study that while the other groups outside the HP Group showed significant collagen discoloration, collagen discoloration in the HP-treated group in sections of every hour of the experiment was localized in the lower part of epidermal layer and did not go up to the depth of dermis compared to the other groups. One of the effects of HP on wound healing can be considered to result from the collagen protective effect and effects on fibroblasts. The study conducted by Ozturk et al. on chicken embryonic fibroblasts also supports our assumption. It is emphasized for the effect of HP that "wound-healing activity of HP extract may be a result of the fibroblast migration and stimulation of collagen synthesis and does not seem to be related to mitotic activity". ${ }^{[20]}$ "However, its effects on epithelization during wound-healing await for further investigations in terms of mechanism of action since previous in vivo experiments with HP extracts have provided evidence for the effect on epithelization. Further studies are recommended to understand responsible compound(s) of HP for wound-healing".[20]
The progression from an injured site to a healed wound is potentially slowed or arrested by a number of different events and conditions. One event that impedes wound healing is colonization of the wound bed by micro-organisms. Various topical treatments have been tried to reduce burn-site infection. Reducing infection also reduces mortality. The golden standard in topical burn treatment is silver sulfadiazine (AgSD), a useful antibacterial agent for burn wound treatment. Recent findings; however, indicate that the compound delays the wound-healing process and that silver may have serious cytotoxic activity on various host cells. ${ }^{[2]}$ On the other hand, the beneficial effects of silver on wound biology due to its potent antimicrobial activity have been overlooked in general until recently. However, compilations which address studies related to silver therapeutics and silver-release dressings treatment state that ${ }^{[22,23]}$ there is "no clear evidence to support the use of silver-containing foam and alginate dressings in the management of infected wounds" ${ }^{[22]}$ and "it is clear also that the effects of the various silver products available on wound infection and wound healing are variable. Understanding the characteristics of these products and dressings may enable them to be targeted more appropriately according to the specific requirements". ${ }^{[23]}$ SS preparations are still used in substantial proportion of burn patients although their effectiveness is uncertain. This is why SS treatment was included into thi study 


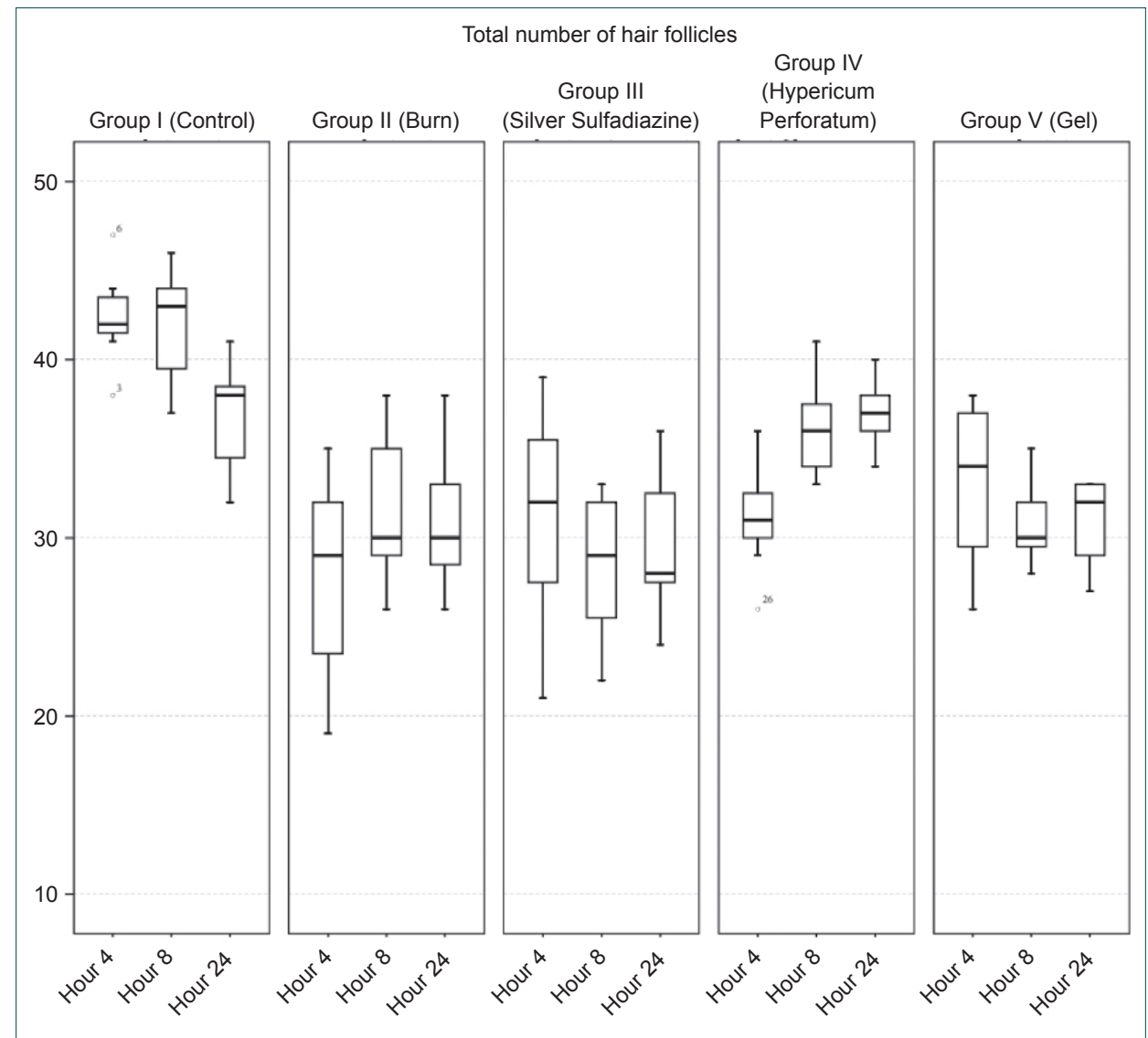

Figure 10. Total number of hair follicles by biopsy hours.

as a group, and it was found that SS treatment was not effective in the acute phase. It was understoodas a result of our study that HP treatment was significantly superior to SS treatment in terms of each wound healing parameter examined histologically. At this point, HP treatment can be considered as an important and powerful alternative to SS treatment.

It is believed that the effects of HP treatment which was found to be significantly effective in acute phase burn injuries result from hyperforin which was first isolated in 1975. Hyperforin-

Table 4. Inter-group comparison of the numbers of degenerated hair follicles of biopsy samples from hours 4,8 and 24

\begin{tabular}{|c|c|c|c|c|c|c|}
\hline $\begin{array}{l}\text { Number of degenerated } \\
\text { hair follicles }\end{array}$ & Groups & Mean & Standard deviation & Median & Minimum & Maximum \\
\hline \multirow[t]{4}{*}{ Hour 4} & Group II (Burn) & 24.00 & 4.16 & 23 & 18 & 29 \\
\hline & Group III (SS) & 23.43 & 4.89 & 23 & 17 & 30 \\
\hline & Group IV (HP) & 11.29 & 2.50 & 12 & 7 & 14 \\
\hline & Group V (Gel) & 19.86 & 2.48 & 20 & 17 & 24 \\
\hline \multirow[t]{4}{*}{ Hour 8} & Group II (Burn) & 28.43 & 3.69 & 27 & 25 & 35 \\
\hline & Group III (SS) & 20.00 & 4.47 & 19 & 15 & 28 \\
\hline & Group IV (HP) & 9.71 & 2.21 & 10 & 6 & 12 \\
\hline & Group V (Gel) & 20.00 & 1.73 & 20 & 18 & 22 \\
\hline \multirow[t]{4}{*}{ Hour 24} & Group II (Burn) & 28.43 & 4.16 & 27 & 24 & 36 \\
\hline & Group III (SS) & 23.43 & 4.93 & 22 & 17 & 30 \\
\hline & Group IV (HP) & 9.57 & 2.07 & 10 & 6 & 12 \\
\hline & Group V (Gel) & 21.00 & 1.15 & 21 & 19 & 22 \\
\hline
\end{tabular}

SS: Silver sulfadiazine; HP: Hypericum perforatum. 


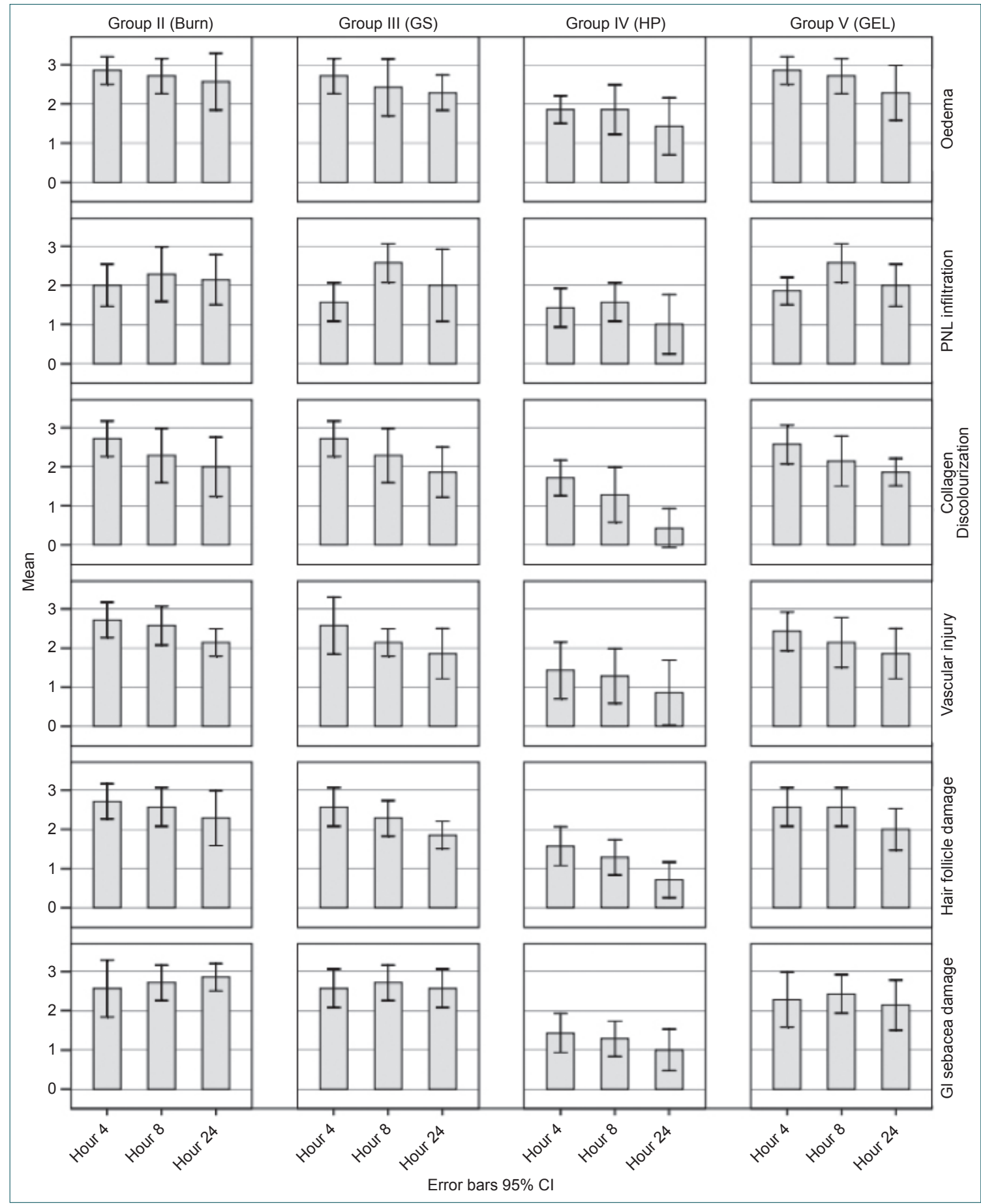

Figure 11. Histopathological scoring of groups by biopsy hours.

related studies suggest that this molecule incorporates antibacterial potency (it was discovered in the studies conducted that Multiresistant Staphylococcus aureus strains was susceptible to hyperforin, and gram-negative bacteria and Candida Albicans also inhibited the growth) antitumoral properties (It inhibited the growth of a wide range of human and rat tumour cell lines by induction of apoptosis in a dose-dependent manner with IC50 values of 3-20 IM), Cytochrome P450 and $\mathrm{P}$-glycoprotein induction and analgesics effects. ${ }^{[24]}$
The final aim in treating burns locally is to speed up skin healing burns and prevent wound site infection. When skin is damaged, pathogens have a direct route to infiltrate the body, potentially resulting in infection. Cutaneous wound repair consists of orderly progression of events that establish the integrity of the damaged tissue. Another reason for HP to be effective in the healing of burn injuries may be its antibacterial and antiviral properties. Studies performed indicate hypericum species antibacterial and antiviral effects. ${ }^{[25]}$ As it 
Table 5. Inter-group comparison of the total numbers of hair follicles of biopsy samples from hours 4,8 and 24

\begin{tabular}{|c|c|c|c|c|c|c|}
\hline Total number of hair follicles & Groups & Mean & Standard deviation & Median & Minimum & Maximum \\
\hline \multirow[t]{5}{*}{ Hour 4} & Group I (Control) & 42.43 & 2.76 & 42 & 38 & 47 \\
\hline & Group II (Burn) & 27.71 & 5.85 & 29 & 19 & 35 \\
\hline & Group III (SS) & 31.14 & 6.41 & 32 & 21 & 39 \\
\hline & Group IV (HP) & 31.14 & 3.13 & 31 & 26 & 36 \\
\hline & Group V (Gel) & 33.00 & 4.73 & 34 & 26 & 38 \\
\hline \multirow[t]{5}{*}{ Hour 8} & Group I (Control) & 41.86 & 3.39 & 43 & 37 & 46 \\
\hline & Group II (Burn) & 31.71 & 4.35 & 30 & 26 & 38 \\
\hline & Group III (SS) & 28.43 & 4.43 & 29 & 22 & 33 \\
\hline & Group IV (HP) & 36.14 & 2.85 & 36 & 33 & 41 \\
\hline & Group V (Gel) & 30.86 & 2.34 & 30 & 28 & 35 \\
\hline \multirow[t]{5}{*}{ Hour 24} & Group I (Control) & 36.71 & 3.15 & 38 & 32 & $4 I$ \\
\hline & Group II (Burn) & 31.00 & 4.04 & 30 & 26 & 38 \\
\hline & Group III (SS) & 29.71 & 4.11 & 28 & 24 & 36 \\
\hline & Group IV (HP) & 37.00 & 1.91 & 37 & 34 & 40 \\
\hline & Group V (Gel) & 30.86 & 2.54 & 32 & 27 & 33 \\
\hline
\end{tabular}

SS: Silver sulfadiazine; HP: Hypericum perforatum.

is known, the first aim of wound management is to keep the wound free of infections and complications. The agents, which help to heal the wound as quickly as possible, are always needed for the contribution of a rapid healing. By accelerating HP epithelialization, reducing the inflammation period and due to its antibacterial properties, it may provide a barrier against microbial contamination at the beginning of the wound healing period. Hypericum species have active antibacterial principles such as hyperforin and flavonoids, which probably contribute to a rapid and better wound healing. ${ }^{[26]}$ Flavonoids are well known active antioxidant compounds responsible for the inhibition of lipid peroxidation, which leads to the prevention of cell damage and increase in the viability of collagen fibrils. ${ }^{[26]}$ Again, it has been shown in a study similar to ours ${ }^{[27]}$ that essential oils in "HP crème mit Rotöl formulation" might possibly promote healing process at the initial steps of wound healing by acting as antimicrobial components.

Another reason for HP to be effective in the healing of burn injuries may be its anti-inflammatory effects. Many studies, like ours, demonstrate HP's anti-inflammatory effects. Hammer et al. ${ }^{[28]}$ have provided further in vitro evidence that flavonoids (quercetin and amentoflavone) along with pseudohypericin and hyperforin might be major anti-inflammatory components. These components were demonstrated to inhibit the production of pro-inflammatory mediators such as prostaglandin E2 (PGE2), tumor necrosis factor- $\alpha$ (TNF- $\alpha$ ) and interleukin-IO (IL-I0), but not enhancing inflammationsuppressing mediators. Hyperforin has been found to act as a dual inhibitor of cyclooxygenase-I and 5-lipoxygenase. ${ }^{[29]}$ Süntar et al. ${ }^{[2]}$ have found out in their study that the anti- inflammatory effects of HP result from that inhibitory effect of the extracts and fractions on the acetic acid-induced increased vascular permeability. It has been emphasized in another study ${ }^{[27]}$ that HP shows a dose-dependent anti-inflammatory activity. This finding may explain contributory role in the wound healing effect of the plant. ${ }^{[12]}$

Another reason for HP to be effective in the healing of burn injuries may be its immuno-modulatory potential. The immunomodulatory potential of polyphenol, lipophile, and water soluble fraction of HP has been examined. ${ }^{[30]}$ The effect on macrophagal activity and humoral and cellular immune responsehas been examined. Polyphenol fraction had immunostimulating effect on the mononuclear phagocyte system and cellular and humoral immunity. Under conditions of high dose tolerance, the polyphenol fraction "promoted regeneration of immunologic activity." The lipophilic portion of the HP had "immunodepressive" properties on cellular and humoral immune response. The immunosuppressive effect of the lipophilic fraction was dose dependent, with the lowest dose producing the maximum effect.

HP extract is used in over 50 cosmetic fomulations and HP oil in just over 10, both across a wide range of product types. Acute toxicity studies using rats, guinea pigs, and mice indicate that the extract is relatively nontoxic. ${ }^{[3]}$ Mixtures containing the extract and the oil were not irritants or sensitizers in animals. Because of the presence of hypericin, HP is a primary photosensitizer. Mutagenic activity in an Ames test has been attributed to flavonols in one study and to quercitin in another, but other genotoxicity assays have been negative. 
Table 6. Group averages by the Modified Verhofstad histopathological scoring ${ }^{[16]}$ system

\begin{tabular}{|c|c|c|c|c|c|}
\hline & & \multicolumn{4}{|c|}{ Experimental groups } \\
\hline & & \multirow{2}{*}{$\frac{\text { Group II (Burn) }}{\text { Mean }}$} & \multirow{2}{*}{$\frac{\text { Group III (SS) }}{\text { Mean }}$} & \multirow{2}{*}{$\frac{\text { Group IV (HP) }}{\text { Mean }}$} & \multirow{2}{*}{$\frac{\text { Group V (Gel) }}{\text { Mean }}$} \\
\hline & & & & & \\
\hline \multicolumn{6}{|l|}{ Histopathological classification } \\
\hline \multirow[t]{3}{*}{ Oedema } & Hour 4 & 2.86 & 2.71 & 1.86 & 2.86 \\
\hline & Hour 8 & 2.71 & 2.43 & 1.86 & 2.71 \\
\hline & Hour 24 & 2.57 & 2.29 & 1.43 & 2.29 \\
\hline \multirow[t]{3}{*}{ PMNL infiltration } & Hour 4 & 2.00 & 1.57 & 1.43 & 1.86 \\
\hline & Hour 8 & 2.29 & 2.57 & 1.57 & 2.57 \\
\hline & Hour 24 & 2.14 & 2.00 & 1.00 & 2.00 \\
\hline \multirow[t]{3}{*}{ Collagen discolourization } & Hour 4 & 2.71 & 2.71 & 1.71 & 2.57 \\
\hline & Hour 8 & 2.29 & 2.29 & 1.29 & 2.14 \\
\hline & Hour 24 & 2.00 & 1.86 & 0.43 & 1.86 \\
\hline \multirow[t]{3}{*}{ Vascular injury } & Hour 4 & 2.71 & 2.57 & 1.43 & 2.43 \\
\hline & Hour 8 & 2.57 & 2.14 & 1.29 & 2.14 \\
\hline & Hour 24 & 2.14 & 1.86 & 0.86 & 1.86 \\
\hline \multirow[t]{3}{*}{ Hair follicle damage } & Hour 4 & 2.71 & 2.57 & 1.57 & 2.57 \\
\hline & Hour 8 & 2.57 & 2.29 & 1.29 & 2.57 \\
\hline & Hour 24 & 2.29 & 1.86 & $0.7 \mathrm{I}$ & 2.00 \\
\hline \multirow[t]{3}{*}{ Gl sebacea damage } & Hour 4 & 2.57 & 2.57 & 1.43 & 2.29 \\
\hline & Hour 8 & 2.71 & 2.71 & 1.29 & 2.43 \\
\hline & Hour 24 & 2.86 & 2.57 & 1.00 & 2.14 \\
\hline
\end{tabular}

SS: Silver sulfadiazine; HP: Hypericum perforatum; PMNL: Polymorphonuclear granulocytes.

No carcinogenicity or reproductive and developmental toxicity data have been available. ${ }^{[31]}$

$\mathrm{HP}$ is effective in wound healing due to its properties such as maintaining epidermal thickness and number of vessels and repairing epidermis within hours (re-epithelialization) and having effects on collagen. These effects may result from enhancing the migration of fibroblasts and collagen deposition and increasing tensile strength or protection of the injury site from infections and inhibition of the inflammatory cells as well as by increasing the connective tissue formation in the repaired tissue. Further studies are warranted in order to explore the detailed mechanism of the wound healing effect of the plant.

Administration of HP four times a day within the first 24 hours is clearly effective in the experimental thermal second degree burn modality and is significantly superior to SS treatment. This treatment which is found to be effective on burns and which is not shown to be allergic, mutagenic and carcinogenic and to have any serious side effects is needed to be used for patients with burns, and there is a need for prospective randomized controlled clinical trials to be conducted in this regard. HP may be an important and powerful treatment alternative for the treatment of acute burn wounds.

\section{Acknowledgement}

This study was supported by the Scientific Research Project of Ege University (2.100.2012.0163).

Conflict of interest: None declared.

\section{REFERENCES}

1. Merck Index. 13th Edition. Merck \& Co., Inc. Whitehouse Station, NJ. 2003.

2. Linde K, Berner MM, Kriston L. St John's wort for major depression. Cochrane Database Syst Rev 2008;4:CD000448. CrossRef

3. Blumenthal M, Busse WR, Goldberg A, Gruenwald J, Hall T, Riggins CW, et al. Klein S, Rister RS (trans.). The Complete German Commission E Monographs-Therapeutic Guide to Herbal Medicines. Austin, TX: American Botanical Council; Boston: Integrative Medicine Communication; 1998.

4. Martinez B, Kasper S, Ruhrmann S, Möller HJ. Hypericum in the treatment of seasonal affective disorders. J Geriatr Psychiatry Neurol 1994;7 Suppl 1:29-33. CrossRef

5. Taylor LH, Kobak KA. An open-label trial of St. John's Wort (Hypericum perforatum) in obsessive-compulsive disorder. J Clin Psychiatry 2000;61:575-8. CrossRef

6. Stevinson C, Ernst E. A pilot study of Hypericum perforatum for the treatment of premenstrual syndrome. BJOG 2000;107:870-6. CrossRef

7. Grube B, Walper A, Wheatley D. St. John's Wort extract: efficacy for 
menopausal symptoms of psychological origin. Adv Ther 1999;16:177-86.

8. Weiss R, Fintelmann V. Herbal Medicine, 2nd ed. New York: Thieme; 2000; 235.

9. Türk Eczacılık Tarihi Simgesi Eczacılık Tarihi Araştırmaları (ed. A.Mat), 3, İstanbul Üniv. Yay. No.4390, Eczacillk Fak. Yay. No.80, Istanbul, 2003.

10. Yeşilada E, Honda G, Sezik E, Tabata M, Goto K, Ikeshiro Y. Traditional medicine in Turkey. IV. Folk medicine in the Mediterranean subdivision. J Ethnopharmacol 1993;39:31-8, CrossRef

11. Yeşilada E, Honda G, Sezik E, Tabata M, Fujita T, Tanaka T, et al. Traditional medicine in Turkey. V. Folk medicine in the inner Taurus Mountains. J Ethnopharmacol 1995;46:133-52. CrossRef

12. Süntar IP, Akkol EK, Yilmazer D, Baykal T, Kirmizibekmez H, Alper M, et al. Investigations on the in vivo wound healing potential of Hypericum perforatum L. J Ethnopharmacol 2010;127:468-77. CrossRef

13. Burn Incidence and Treatment in the United States: 2011 Fact Sheet, American Burn Association. Available at http://www.ameriburn.org.

14. Korompai FL, Yuan SY. Ventral burn in rats: an experimental model for intravital microscopic study of microcirculation. Burns 2002;28:321-7.

15. Saitoh D, Shirani KZ, Cioffi WG, Kizaki T, Ohno H, Okada Y, et al. Changes in the tissue and plasma superoxide dismutase (SOD) levels in a burned rat model. Tohoku J Exp Med 2001;193:27-36. CrossRef

16. Songur MK, Akdemir O, Lineaweaver WC, Cavusoglu T, Ozsarac $\mathrm{M}$, Aktug $\mathrm{H}$, et al. Comparison of skin effects of immediate treatment modalities in experimentally induced hydrofluoric acid skin burns. Int Wound J 2014 Jan 29. CrossRef

17. Akhoondinasab MR, Khodarahmi A, Akhoondinasab M, Saberi M, Iranpour M. Assessing effect of three herbal medicines in second and third degree burns in rats and comparison with silver sulfadiazine ointment. Burns 2015;41:125-31. CrossRef

18. Chvapil M, Chvapil TA, Owen JA. Reaction of various skin wounds in the rat to collagen sponge dressing. J Surg Res 1986;41:410-8. CrossRef

19. Motta G, Ratto GB, De Barbieri A, Corte G, Zardi L, Sacco A, et al. Can heterologous collagen enhance the granulation tissue growth? An experimental study. Ital J Surg Sci 1983;13:101-8.
20. Oztürk N, Korkmaz S, Oztürk Y. Wound-healing activity of St. John's Wort (Hypericum perforatum L.) on chicken embryonic fibroblasts. J Ethnopharmacol 2007;111:33-9. CrossRef

21. Fraser JF, Cuttle L, Kempf M, Kimble RM. Cytotoxicity of topical antimicrobial agents used in burn wounds in Australasia. ANZ J Surg 2004;74:139-42. CrossRef

22. Beam JW. Topical silver for infected wounds. J Athl Train 2009;44:5313. CrossRef

23. Atiyeh BS, Costagliola M, Hayek SN, Dibo SA. Effect of silver on burn wound infection control and healing: review of the literature. Burns 2007;33:139-48. CrossRef

24. Beerhues L. Hyperforin. Phytochemistry 2006;67:2201-7. CrossRef

25. Cecchini C, Cresci A, Coman MM, Ricciutelli M, Sagratini G, Vittori S, et al. Antimicrobial activity of seven hypericum entities from central Italy. Planta Med 2007;73:564-6. CrossRef

26. Shetty S, Udupa S, Udupa L. Evaluation of Antioxidant and Wound Healing Effects of Alcoholic and Aqueous Extract of Ocimum sanctum Linn in Rats. Evid Based Complement Alternat Med 2008;5:95-101.

27. Süntar I, Akkol EK, Keleş H, Oktem A, Başer KH, Yeşilada E. A novel wound healing ointment: a formulation of Hypericum perforatum oil and sage and oregano essential oils based on traditional Turkish knowledge. J Ethnopharmacol 2011;134:89-96. CrossRef

28. Hammer KD, Hillwig ML, Solco AK, Dixon PM, Delate K, Murphy PA, et al. Inhibition of prostaglandin $\mathrm{E}(2)$ production by anti-inflammatory hypericum perforatum extracts and constituents in RAW264.7 Mouse Macrophage Cells. J Agric Food Chem 2007;55:7323-31. CrossRef

29. Albert D, Zündorf I, Dingermann T, Müller WE, Steinhilber D, Werz O. Hyperforin is a dual inhibitor of cyclooxygenase-1 and 5-lipoxygenase. Biochem Pharmacol 2002;64:1767-75. CrossRef

30. Evstifeeva TA, Sibiriak SV. The immunotropic properties of biologically active products obtained from Klamath weed (Hypericum perforatum L.). [Article in Russian] Eksp Klin Farmakol 1996;59:51-4. [Abstract]

31. Final report on the safety assessment of Hypericum perforatum extract and Hypericum perforatum oil. Int J Toxicol 2001;20 Suppl 2:31-9. CrossRef

\title{
DENEYSEL ÇALIŞMA - ÖZET
}

\section{Deneysel haşlama tipi yanıklarda Hypericum perforatum (Kantaron) tedavisinin akut etkilerinin araştırılması ve gümüş sülfadiazin tedavisiyle karşılaştırılması \\ Dr. Selahattin Kıyan, ${ }^{1}$ Dr. Yiğit Uyanıkgil,, ${ }^{2}$ Dr. Yusuf Ali Altuncı, ${ }^{1}$ Dr. Türker Çavuşoğlu, ${ }^{2}$ Emel Öykü Çetin Uyanıkgil, ${ }^{3}$ Dr. Fatih Karabey ${ }^{4}$}

\author{
${ }^{1}$ Ege Üniversitesi Tıp Fakültesi, Acil Tıp Anabilim Dalı, İzmir \\ ${ }^{2}$ Ege Üniversitesi Tıp Fakültesi, Histoloji ve Embriyoloji Anabilim Dalı, Kordon Kanı, Hücre ve Doku Araştırma ve Uygulama Merkezi, İzmir \\ ${ }^{3}$ Ege Üniversitesi Tıp Fakültesi, Eczacılık Fakültesi, Biyofarmatik ve Farmakokinetik Anabilim Dalı, İzmir \\ ${ }^{4}$ Ege Üniversitesi Fen Fakültesi, Biyoloji Bölümü, İzmir
}

AMAÇ: Hypericum perforatum (HP), Türkiye'de yıllardır halk arasında yanık yaralarının tedavisinde kullanılmaktadır. Bu çalışmada, deneysel haşlama tipi yanıklarda HP tedavisinin akut etkilerinin araştııııması ve gümüş sülfadiazin (GS) tedavisiyle karşılaştııılması amaçlandı.

GEREÇ VE YÖNTEM: Her grupta yedi adet olacak şekilde toplam beş grupta 35 sıçan kullanıldı. Sıçanların sırt bölgesinde $4 \times 4 \mathrm{~cm}$ 'lik alan I00 ${ }^{\circ} \mathrm{C}$ suya 10 saniye maruz bırakılarak haşlama tipi ikinci derece yanık oluşturuldu. 50 cc serum fizyolojik (SF) ile tüm gruplara üç dakika boyunca irrigasyon sağlandı. Grup I (kontrol grubu) herhangi bir tedavi uygulanmadı. Grup 2 (yanık kontrol grubu) sadece irrigasyon, Grup 3 [topikal gümüş sülfadiazin (GS)] GS günde iki kez, Grup 4 (topikal HP grubu) HP günde dört kez (altı saatte bir), Grup 5 (aracı ile -jel- tedavi) HP hazırlanmasında kullanılan diğer topikal materyal günde dört kez (altı saatte bir) uygulandı. Dördüncü, sekizinci ve yirmi dördüncü saatlerde sıçan sırt derisinden kare biçiminde $|x| \mathrm{cm}$ boyutlarında insizyonel biyopsiler alındı. Derideki yara yeri iyileşmesi bulguları histopatolojik olarak değerlendirildi.

BULGULAR: Hypericum perforatum grubunun epidermis kalılığııı ve damar sayısının diğer gruplara göre anlamlı oranda $(p<0.05)$ daha fazla olduğu bu parametreler açısından kontrol grubuna en yakın grup olduğu ve saatler içerisinde de bu sayıların farklılık göstermediği saptandı ( $p>0.05$ ). Tüm gruplara göre HP grubunda dejenere kıl kökü sayısı anlamlı oranda daha azdı $(p<0.05)$ ve 24. saatlerde toplam kıl kökü sayısında anlamlı oranda artışın olduğu $(p<0.05)$ ve bu sayının kontrol grubuyla farklılık göstermediği $(p>0.05)$ saptandı.

TARTIŞMA: Deneysel haşlama tipi ikinci derece yanık modelinde HP'nin ilk 24 saatte günde dört defa uygulanması net bir şekilde yanık yara iyileşmesinde etkilidir ve GS tedavisinden ciddi anlamda üstündür.

Anahtar sözcükler: Gümüş sülfadiazin; Hypericum perforatum; yanık; yara iyileşmesi.

Ulus Travma Acil Cerrahi Derg 20I5;2I (5):323-336 doi: 10.5505/tjtes.20I5.63822 